\title{
Improving the efficiency of a direct ethanol fuel cell by a periodic load change
}

\author{
Andrzej Jablonski, Adam Lewera* \\ Department of Chemistry, University of Warsaw, ul. Pasteura 1, 02-093 Warsaw, Poland
}

\section{A R T I C L E I N F O}

Article history:

Received 20 July 2014

Accepted 12 September 2014

Published 20 April 2015

\section{Keywords:}

Ethanol electrooxidation

Electrocatalysis

Direct ethanol fuel cell

Polymer electrolyte membrane fuel cell

Platinum

Platinum-ruthenium

\begin{abstract}
A B S T R A C T
We present a simple method to increase the efficiency of a direct ethanol fuel cell by a periodic modulation of the load (pulsed mode). The fuel cell was periodically short circuited with a resistor $(1 \Omega$ ) for a few seconds (high load period) followed by a low load period of up to $100 \mathrm{~s}$ when the resistor was disconnected. The open circuit voltage (OCV) values before and after the short circuit of the cell showed an increase of up to $70 \mathrm{mV}$. The higher OCV was due to the oxidation and removal of strongly adsorbed CO during the electric short circuit when the electric potential of the anode was increased to be close to the cathode potential. The depoisoned anode surface was much more active directly after the short circuit. The slow decrease of the OCV observed after the short circuit was caused by the subsequent poisoning of the anode surface, which can be neutralized by another short circuit. In general, a stable increase in cell performance was obtained by repetition of the electric short circuit. The data showed that the pulse mode gave an increase in the power generated by the direct ethanol fuel cell by up to $51 \%$ and was $6 \%$ on average. It is anticipated that this mode of operation can be used also in different types of polymer electrolyte membrane fuel cells where CO poisoning is a problem, and after optimization of the parameters, a much higher gain in efficiency can be obtained.
\end{abstract}

(C) 2015, Dalian Institute of Chemical Physics, Chinese Academy of Sciences. Published by Elsevier B.V. All rights reserved.

\section{Introduction}

Direct ethanol fuel cells (DEFCs) are a subclass of polymer electrolyte membrane fuel cells (PEMFCs) that have many potential advantages over other types of fuel cells (FCs), but currently there are no anode, cathode, and membrane materials that give a high efficiency [1-8]. Three important obstacles are: (1) low activity of the anode and cathode catalysts [2-5,9-12], (2) low durability of the membrane, especially at elevated temperature [13-15], and (3) permeability of the membrane to fuel and oxidizer [15-17]. Even with the most active anode catalysts, which are noble metal nanoparticles, ethanol oxidation only occurs with a high overpotential and gives a low se- lectivity to $\mathrm{CO}_{2}$ [18-23], the product of the complete oxidation of ethanol. Different approaches have been tested to increase the activity of the anode and cathode catalysts, including changing the catalyst support [8] and the preparation of ultra-pure [24] and bi- or multicomponent catalysts [10-12, 25-28]. Changes in cell design, including membraneless cells, have also been proposed to increase efficiency $[29,30]$.

It is known that the incomplete electrooxidation of ethanol on Pt leads to CO as one of the products [31]. CO strongly adsorbs on the surface of the Pt electrode and significantly decreases its catalytic activity [31]. It has been also observed that alloying Pt with other metals can increase the catalytic activity by a bifunctional mechanism. In bimetallic systems, ethanol 
adsorbs on Pt while the second metal provides adsorbed $\mathrm{OH}$ groups. When $\mathrm{CO}$ is produced, adsorbed $\mathrm{OH}$ groups facilitate its removal by the oxidation of $\mathrm{CO}$ to $\mathrm{CO}_{2}$. This mechanism was described for the first time by Watanabe and Motoo [32,33] for methanol electrooxidation on $\mathrm{Pt}$-Ru, but it is valid also for ethanol electrooxidation. The main difference is that in the case of ethanol electrooxidation, the $\mathrm{OH}$ groups on the second metal promote the formation of acetic acid (another product of the incomplete oxidation of ethanol) [16,23], which is a dead end for the electrooxidation of ethanol in low temperature fuel cells $[34,35]$. This is why another method for the removal of CO from the catalyst surface is needed for DEFCs. Here we present a simple method to de-poison the anode catalyst surface by a momentary increase of the anode potential, which caused the oxidation and removal of adsorbed $\mathrm{CO}$ from the catalyst surface. As a result, an increase in the open circuit voltage (OCV) and in the amount of power generated was observed.

\section{Experimental}

Analytical grade 96\% ethanol (POCh, Gliwice, Poland) and MilliQ (18 $\mathrm{M} \Omega \mathrm{cm}$ ) water were used to prepare the ethanol solution (anode fuel). The anode catalyst (4-6 nm Pt or 1:1 Pt-Ru nanoparticles, 20\% metal loading on Vulcan XC-72) and cathode catalyst (4-6 nm Pt nanoparticles, 40\% metal loading on Vulcan XC-72) were manufactured by BASF. High purity (N5.2) $\mathrm{O}_{2}$ from Air Products Inc. (Poland) was used as the cathode gas. Fuel cells from Fuel Cell Technologies Inc. were used, which consisted of two graphite plates with a single serpentine flow pattern and $10 \mathrm{~cm}^{2}$ active area. The cell voltage and current were controlled using an EG\&G Princeton Applied Research 362 Scanning Potentiostat and collected using a National Instruments NI USB-6211 data acquisition card connected to the $I$ and $E$ monitors of the potentiostat. Fuel was fed by a peristaltic pump at $1.56 \mathrm{~cm}^{3} / \mathrm{min}$ flow rate. The fuel cell membrane-electrode assembly (MEA) preparation has been described elsewhere [19]. The membrane-electrode assemblies were prepared by painting the catalyst suspension onto DuPont Nafion 117 pretreated by boiling in $0.5 \mathrm{~mol} / \mathrm{L} \mathrm{H}_{2} \mathrm{SO}_{4}$ for $3 \mathrm{~h}$ prior to the catalyst deposition. For the anode, either $\mathrm{Pt}$ or Pt-Ru nanoparticles with $20 \%$ metal by mass on Vulcan XC-72 (BASF) or a loading of $1 \mathrm{mg}$ (metal) $/ \mathrm{cm}^{2}$ was used. For the cathode, Pt nanoparticles with $40 \%$ Pt by mass on Vulcan

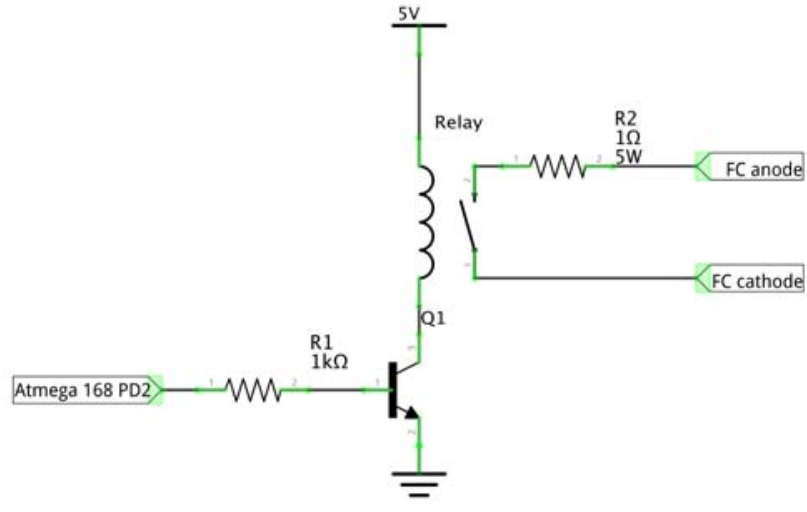

Fig. 1. Electronic schematic of the interface used for short circuiting the cell with a resistor $(1 \Omega)$.

XC-72 or a loading of $1 \mathrm{mg}$ (metal) $/ \mathrm{cm}^{2}$ was used. The catalyst suspension used for the anode and cathode was prepared using water and $5 \%$ Nafion solution in ethanol (Aldrich) (1:1 by volume). The amount of liquid in the suspension was adjusted to give $30 \%$ by weight of Nafion in the dried total catalyst mass after deposition. Gas diffusion layers $\left(10 \mathrm{~cm}^{2}\right.$ pieces of carbon paper from Toray) were added on both sides of the membrane before cell assembly.

The fuel cell was short circuited using a resistor $(1 \Omega 5 \mathrm{~W})$. The use of a small resistance was to simulate a low resistance load. The short circuit current was not measured. To give a periodic shorting of the fuel cell, a mechanical relay (Panasonic TX2SA-5V) controlled by an Atmel ATmega 168 microcontroller and a simple program for the microcontroller were used. A simple electronic interface to drive the mechanic relay from the microcontroller was made (Fig. 1), which consisted of a current limiting resistor (R1) and a general purpose NPN transistor (BC548) to drive the relay.

$\mathrm{CO}_{2}$ amount was recorded using a GE Measurement \& Control/GE Sensing Telaire T6615 NDIR 0-2000 ppm CO2 sensor. A diffusion cell was used to separate gaseous $\mathrm{CO}_{2}$ from the liquid product leaving the fuel cell anode. The diffusion cell consisted of two cavities, $10 \mathrm{~mm}$ wide, $100 \mathrm{~mm}$ long, and $1 \mathrm{~mm}$ deep, separated by the semipermeable Nafion 112 membrane (Fig. 2(i)) with inlet and outlet connections at both ends. One half (one cavity) of the diffusion cell was connected directly to the fuel cell anode outlet (Fig. 2, port c connected to port e), and the

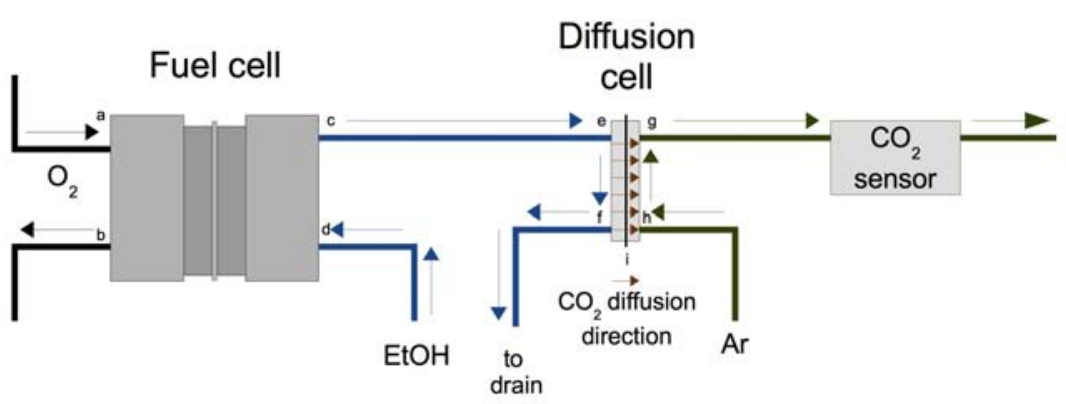

Fig. 2. Schematic drawing of the experimental set-up. (a) FC cathode inlet; (b) FC cathode outlet; (c) FC anode outlet; (d) FC anode inlet; (e) diffusion cell liquid inlet (connected to FC anode outlet); (f) diffusion cell liquid outlet; (g) diffusion cell gas outlet; (h) diffusion cell gas inlet; (i) semipermeable Nafion 112 membrane. Liquid fuel path is marked in blue, and path of carrier gas (Ar) and $\mathrm{CO}_{2}$ from the FC anode (gaseous) is marked in green. Brown arrows in the diffusion cell mark the direction of $\mathrm{CO}_{2}$ diffusion from the liquid leaving the $\mathrm{FC}$ anode outlet to the carrier gas (Ar) stream. 
outlet from this cavity (port f) was connected to drain. The second half of the diffusion cell (port h) was connected to an $\mathrm{Ar}$ supply, and the outlet from this half (port g) was connected to the NDIR $\mathrm{CO}_{2}$ sensor. This resulted in a configuration with a constant stream of anode product flowing in one cavity (from port e to port f) and an Ar stream flowing in countercurrent manner in the other cavity (from port h to port g). The streams were separated by the semipermeable Nafion membrane (i). In the diffusion cell, $\mathrm{CO}_{2}$ that was dissolved in the liquid leaving the fuel cell anode diffused into the Ar stream through the Nafion 112 membrane and was sent to the NDIR sensor. This setup was characterized by a dead time of $180 \mathrm{~s}$. The $\mathrm{Ar}$ and $\mathrm{O}_{2}$ flows were controlled using Sierra Instruments SmartTrak® 50 mass flow controllers.

\section{Results and discussion}

Working DEFCs with either a Pt or Pt-Ru anode were subjected to periodic electric short circuits of the anode and cathode using a resistor $(1 \Omega)$. The time of the electric short circuit ( $\left.t_{\text {short }}\right)$ and interval between shorts (relaxation time, $\left.t_{\text {rel }}\right)$ were controlled using a microcontroller device described in the Experimental section (Fig. 1). To distinguish between the cases when the cell was periodically shorted and when the cell worked under typical no shorting conditions (for efficiency comparison), these conditions are referred to as "pulsed mode" and "static mode", respectively. A representative plot of the OCV versus time for a DEFC with a Pt anode working in the pulsed and static modes is presented in Fig. 3.

It was observed that in the pulsed mode, the average OCV value was significantly higher than the OCV value in the static mode (Fig. 3). In particular, just after the short circuit, the OCV reached $600 \mathrm{mV}$ and was relatively stable for the following $20 \mathrm{~s}$ and then started to decrease, reaching $550 \mathrm{mV} 50 \mathrm{~s}$ after the short circuit and $530 \mathrm{mV} 100 \mathrm{~s}$ after the short circuit (Fig. 3, inset (A)). During the electric short circuit, the cell voltage was $50 \mathrm{mV}$ for the whole duration of the electric short circuit. A similar observation was made when the cell worked under a

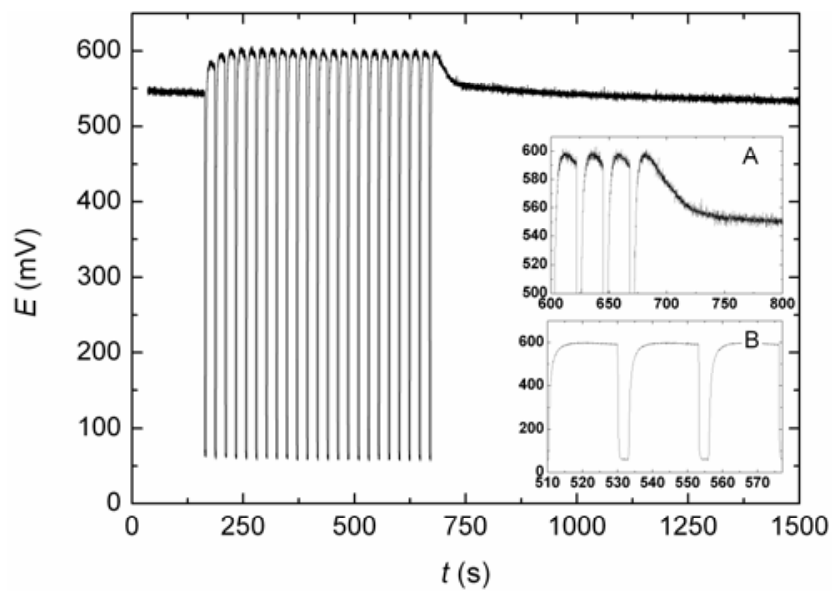

Fig. 3. OCV of a DEFC (Pt anode/Pt cathode, $0.2 \mathrm{~mol} / \mathrm{L} \mathrm{EtOH}, 15 \mathrm{ml} / \mathrm{min}$ $\mathrm{O}_{2}, 90{ }^{\circ} \mathrm{C}$ ) in pulsed mode (between 150 and $700 \mathrm{~s}$ ) followed by the static mode (after $700 \mathrm{~s}$ ). Two regions of this plot are presented in more detail in inset $(\mathrm{A})$ and inset (B). load. Typical $E$ and $I$ versus time plots are presented in Fig. 4

Under a constant load (resistance), the cell delivered 120 $\mathrm{mA}$ at $310 \mathrm{mV}$ (Fig. 4). In the pulsed mode with the same load, the cell delivered up to $140 \mathrm{~mA}$ at $360 \mathrm{mV}$. The $E$ versus $t$ dependence had a different shape under a load as compared to $E$ versus $t$ plot recorded for the open circuit (OC) conditions (cf. Inset to Fig. 4(A) and Inset (B) to Fig. 3). A fuel cell with a Pt-Ru anode was also investigated. A similar increase in cell OCV as with the Pt anode (Fig. 3) was observed in the pulsed mode (Fig. 5). In the pulsed mode, the OCV reached $600 \mathrm{mV}$, as compared to the static mode when the OCV was $530 \mathrm{mV}$ (Fig. 5).

As shown in Figs. 3 and 5, when the DEFC was working in the pulsed mode, it delivered a higher OCV. An OCV increase was observed with both $\mathrm{Pt}$ and Pt-Ru anode catalysts (Figs. 3 and 5, respectively). Also, when the cell was under a load, in the pulsed mode, a higher cell current and higher cell voltage between pulses were recorded for Pt (Fig. 4) and Pt-Ru, which resulted in a higher cell power in the pulsed mode as compared to the static mode (Fig. 6).

When the cell was working in the pulsed mode, the maximum power generated by the fuel cell, directly after the short circuit, was $53 \mathrm{~mW}$ as compared to $35 \mathrm{~mW}$ in the static mode
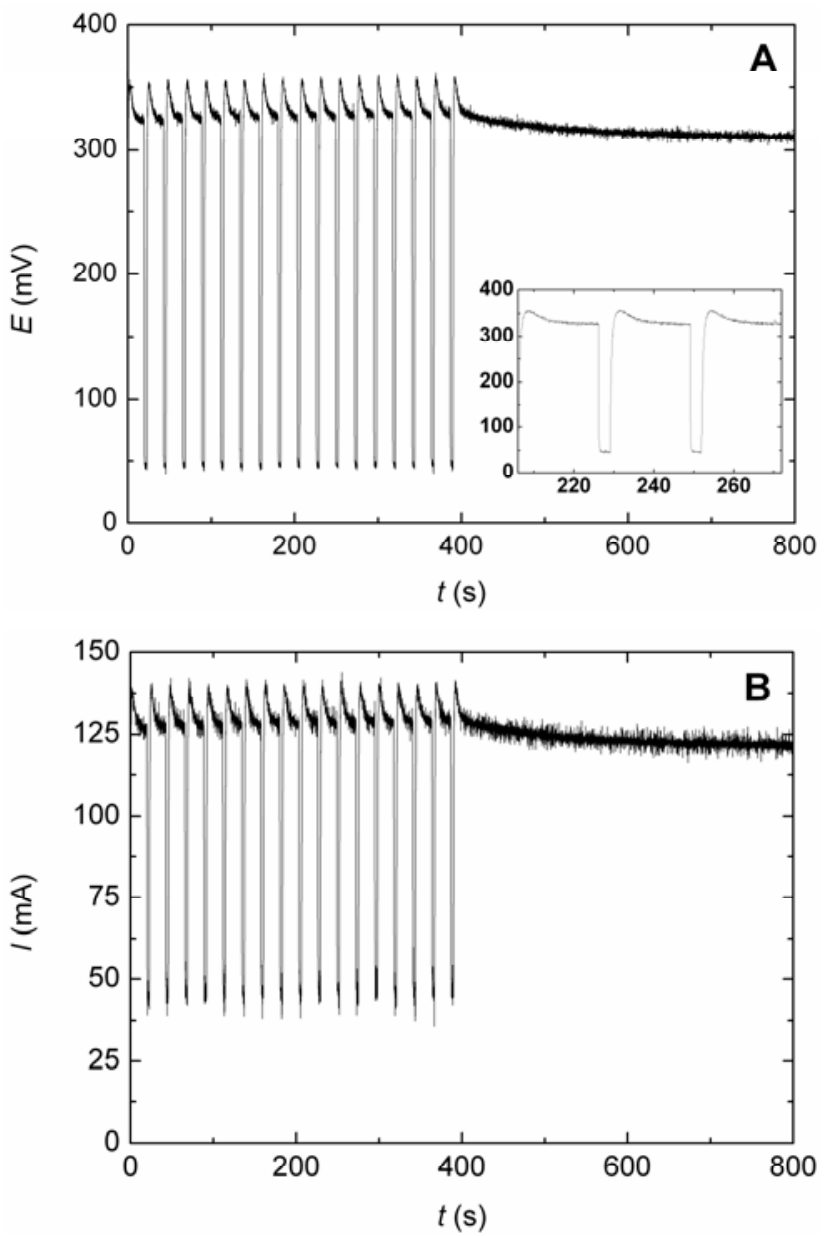

Fig. 4. Cell voltage (A) and external circuit current (B) for a DEFC under load. Pt anode/Pt cathode, $0.2 \mathrm{~mol} / \mathrm{L} \mathrm{EtOH}, 15 \mathrm{ml} / \mathrm{min} \mathrm{O}_{2}$, $90^{\circ} \mathrm{C}$. Cell pulsed mode for first $400 \mathrm{~s}$, then in standard mode for an additional $400 \mathrm{~s}$. Inset to Fig. 4(A) shows the $E$ vs $t$ dependence for three consecutive pulses. 


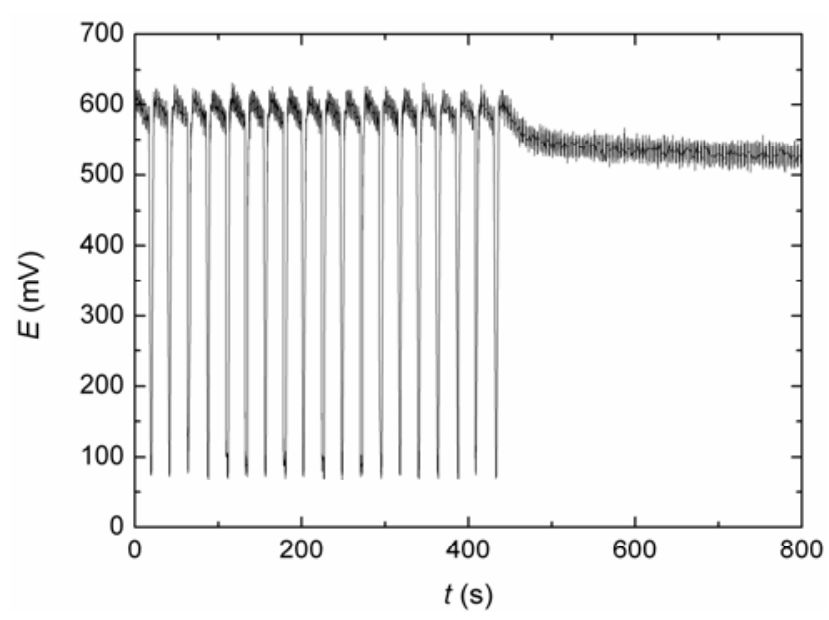

Fig. 5. DEFC voltage under OC conditions under pulsed (first $450 \mathrm{~s}$ ) and static (after $450 \mathrm{~s}$ ) conditions. Pt-Ru anode/Pt cathode, 2 mol/L EtOH, $15 \mathrm{ml} / \mathrm{s} \mathrm{O}_{2}, 80^{\circ} \mathrm{C}$.

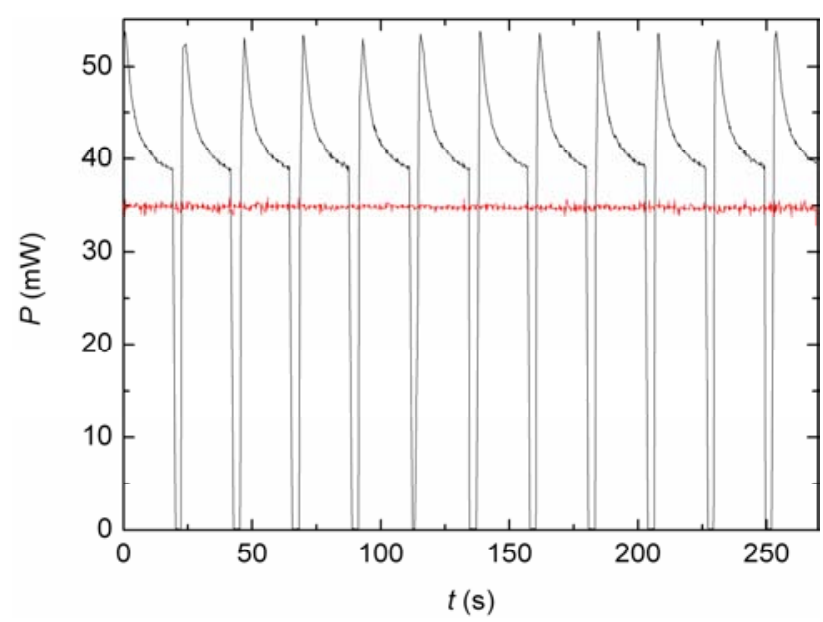

Fig. 6. Comparison of DEFC power under pulsed (black) and static (red) conditions. Pt-Ru anode/Pt cathode, $2 \mathrm{~mol} / \mathrm{L} \mathrm{EtOH}, 15 \mathrm{ml} / \mathrm{s} \mathrm{O}_{2}, 80^{\circ} \mathrm{C}$.

(Fig. 6). This was 51\% increase in the cell power. However, the cell power between electric short circuits decreased with time (Fig. 6), and the maximum power was obtained for only a few seconds after the short circuit (Fig. 6). Nevertheless for the whole period between electric short circuits, the cell generated a higher power as compared to the cell working in the static mode (Fig. 6). Obviously, during the electric short circuit, the power of the cell was close to zero, and because of the variation in power between short circuits, the more useful parameter for comparing the cell performance in pulsed and static modes was the total amount of energy delivered by the cell as a function of time (Fig. 7).

The slope (first derivative) of $W$ versus $t$ (Fig. 7) is the cell power. It can be observed (Fig. 7) that the total amount of energy delivered by the FC was higher when the cell worked in pulsed mode despite the fact that in the pulsed mode and during the electric short circuit, the energy output was assumed to be zero. In particular, $6 \%$ increase in the cell power in the pulsed mode was observed, which was measured as the slope difference between the two lines in Fig. 7, which changed from 35 to $37 \mathrm{~mW}$. This provided proof that on average the addi-

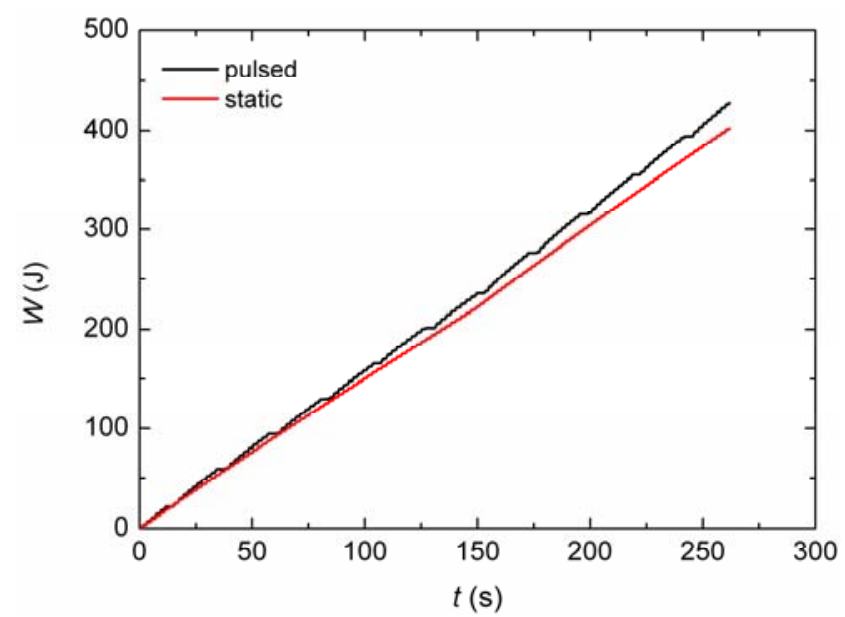

Fig. 7. Comparison of energy delivered by the DEFC vs time under pulsed (black) and static (red) conditions. Pt-Ru anode/Pt cathode, 2 mol/L EtOH, $15 \mathrm{ml} / \mathrm{s} \mathrm{O}_{2}, 80^{\circ} \mathrm{C}$.

tional amount of energy obtained between short circuits offsets the gaps in energy output during the short circuit (Fig. 7). The energy assumed to be lost can also be utilized, which would lead to an even higher energy output (higher power) in the pulsed mode. The optimum working conditions of the cell can be obtained by fine tuning the pulsed mode parameters, such as the short circuit time and relaxation time (Fig. 8).

From Fig. 8, it was observed that the OCV increase depended on pulse time and relaxation time. For $t_{\text {short }}$ less than $1 \mathrm{~s}$, the OCV increase was significant, but for a longer short circuit time, the gain in the OCV decreased and the OCV was almost constant. Obviously, during a longer $t_{\text {short, }}$ more energy was wasted, thus for practical application, $t_{\text {short }}$ must be optimized taking into account both cell voltage increase and amount of energy lost during the short circuit, as both factors increased at different rates with $t_{\text {short. }}$ It was anticipated that a $t_{\text {short }}$ time equal to or shorter than $1 \mathrm{~s}$ was optimal. The dependence between OCV and relaxation time reached a maximum for $5 \mathrm{~s}$ and then declined slowly (Fig. 8). Based on Fig. 8, it was clear that the relaxation time should not be shorter than $5 \mathrm{~s}$. In general, $t_{\text {short }}$
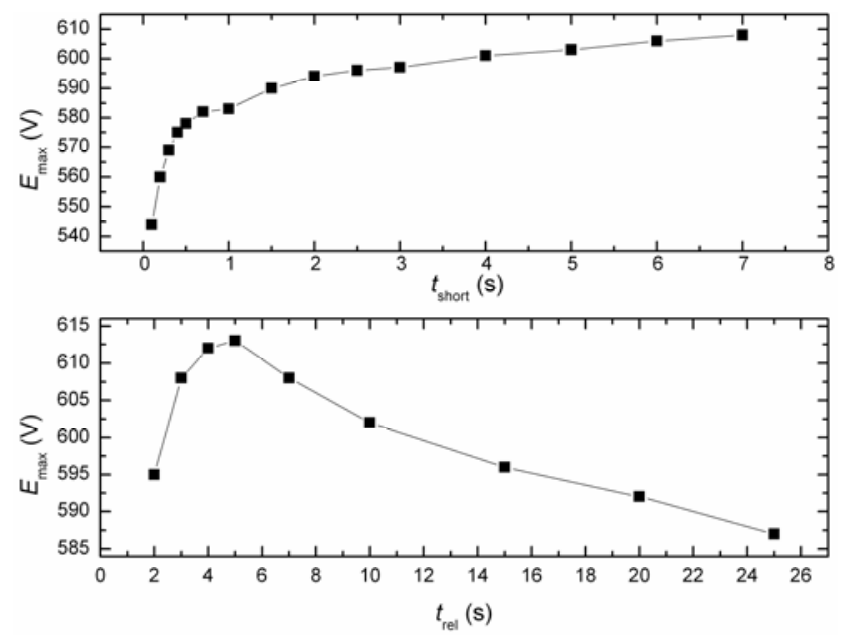

Fig. 8. OCV vs short circuit time $\left(t_{\text {short }}\right)$ and relaxation time $\left(t_{\text {rel }}\right)$. Pt-Ru anode/Pt cathode, $2 \mathrm{~mol} / \mathrm{L} \mathrm{EtOH}, 15 \mathrm{ml} / \mathrm{s}_{2}, 80^{\circ} \mathrm{C}$. 
and $t_{\text {rel }}$ were dependent on the experimental conditions, but the detailed optimization of these parameters for different conditions was out of the scope of this report.

It is worthwhile to note that instead of a low resistance, which during the short circuit dissipated energy in the form of heat, a low resistance load or energy storage device (such as capacitor) can be used to store the energy for later use, which will increase the efficiency of the fuel cell working in the pulsed mode.

To determine the cause of increased cell performance in the pulsed mode, the amount of $\mathrm{CO}_{2}$ produced by the fuel cell was determined. An increased production of $\mathrm{CO}_{2}$ in the pulsed mode was observed (Fig. 9). The delay in the response of the $\mathrm{CO}_{2}$ sensor was caused by a dead time of the setup used for $\mathrm{CO}_{2}$ detection (see Experimental).

The increased $\mathrm{CO}_{2}$ yield (Fig. 9) in the pulsed mode explained the increased performance of the fuel cell. During the oxidation of ethanol in the fuel cell, the surface of the catalysts becomes poisoned by adsorbed $\mathrm{CO}$, and short circuiting of the fuel cell caused $\mathrm{CO}$ oxidation to $\mathrm{CO}_{2}$ and surface de-poisoning. CO oxidation during the electric short circuit occurred because there was an increase in the electric potential of the anode to the value of cathode potential (which was at $800 \mathrm{mV}$, the potential for oxygen reduction on $\mathrm{Pt}$ ), and CO can be easily oxidized at that potential. As a result, after the electric short circuit, the catalyst surface was free of adsorbed CO, which significantly increased catalytic activity. This increase in catalytic activity lasted for up to $100 \mathrm{~s}$ (Fig. 3). The subsequent decrease in catalytic activity to the level typical of the cell working in the static mode was caused by CO build-up on the anode catalyst surface. When the catalytic activity dropped, another electric short circuit was applied, and the whole process repeated, which resulted in an overall higher cell performance in the
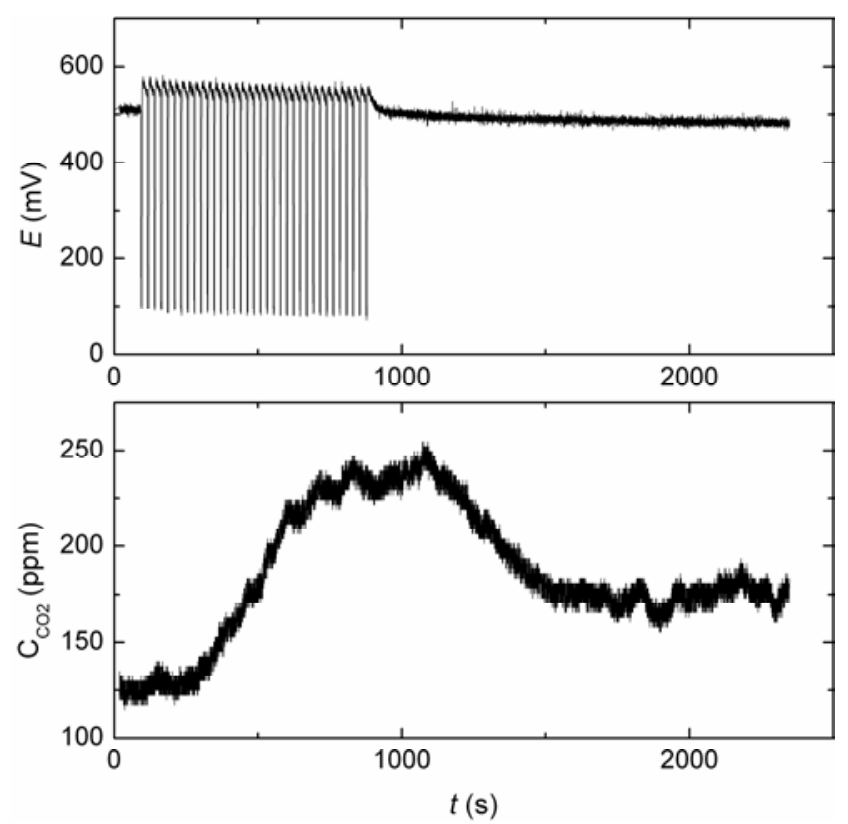

Fig. 9. Simultaneously recorded DEFC voltage (OC conditions) and $\mathrm{CO}_{2}$ concentration at the anode outlet. Pt-Ru anode/Pt cathode, $5 \mathrm{~mol} / \mathrm{L}$ $\mathrm{EtOH}, 15 \mathrm{ml} / \mathrm{s}_{2}, 80^{\circ} \mathrm{C}$. pulsed mode (Fig. 7).

Obviously during the short circuit, not only CO but also ethanol can be oxidized. The oxidation of ethanol leads to a decrease in fuel cell efficiency. Thus it is important to keep the short circuit time as short as possible and just long enough to oxidize CO. Obviously, the higher amount of CO produced by the fuel cell working in the pulsed mode (Fig. 9) can be the result of any (or both) of the processes described above. The oxidation of $\mathrm{CO}$ or ethanol to $\mathrm{CO}_{2}$ cannot be easily differentiated in the working fuel cell, thus more work is needed to better understand the processes occurring in the fuel cell working in the pulsed mode. It is also anticipated that with other anodes and other organic fuels, the behavior can be similar. This will be investigated in more detail soon.

\section{Conclusions}

Periodic short circuit of the DEFC electrodes increased both the OCV and efficiency of a DEFC with either a Pt or Pt-Ru anode. When the fuel cell worked in the pulsed mode, a $70 \mathrm{mV}$ increase in OCV was observed. The cell power was increased in the pulsed mode from $35 \mathrm{~mW}$ in the static mode to a maximum of $53 \mathrm{~mW}$ (51\% increase) and to $37 \mathrm{~mW}$ on average $(6 \%$ increase).

\section{References}

[1] Song S Q, Tsiakaras P. Appl Catal B, 2006, 63: 187

[2] Lamy C, Belgsir E M, Leger J M. J Appl Electrochem, 2001, 31: 799

[3] Antolini E.J Power Sources, 2007, 170: 1

[4] Zhou W J, Zhou Z H, Song S Q, Li W Z, Sun G Q, Tsiakaras P, Xin Q. Appl Catal B, 2003, 46: 273

[5] Song S Q, Zhou W J, Zhou Z H, Jiang L H, Sun G Q, Xin Q, Leontidis V, Kontou S, Tsiakaras P. Int J Hydrogen Energy, 2005, 30: 995

[6] Brouzgou A, Podias A, Tsiakaras P. J Appl Electrochem, 2013, 43: 119

[7] Brouzgou A, Song S Q Tsiakaras P. Appl Catal B, 2012, 127: 371

[8] Nakagawa N, Ito Y, Tsujiguchi T, Ishitobi H. J Power Sources, 2014, 248: 330

[9] Nakagawa N, Kaneda Y, Wagatsuma M, Tsujiguchi T. J Power Sources, 2012, 199: 103

[10] Zhou W J, Song S Q Li W Z, Sun G Q, Xin Q, Kontou S, Poulianitis K, Tsiakaras P. Solid State Ionics, 2004, 175: 797

[11] Zhou W J, Li W Z, Song S Q, Zhou Z H, Jiang L H, Sun G Q, Xin Q, Poulianitis K, Kontou S, Tsiakaras P. J Power Sources, 2004, 131: 217

[12] Lamy C, Rousseau S, Belgsir E M, Coutanceau C, Leger J M. Electrochim Acta, 2004, 49: 3901

[13] Borup R, Meyers J, Pivovar B, Kim Y S, Mukundan R, Garland N, Myers D, Wilson M, Garzon F, Wood D, Zelenay P, More K, Stroh K, Zawodzinski T, Boncella J, McGrath J E, Inaba M, Miyatake K, Hori M, Ota K, Ogumi Z, Miyata S, Nishikata A, Siroma Z, Uchimoto Y, Yasuda K, Kimijima K I, Iwashita N. Chem Rev, 2007, 107: 3904

[14] Collier A, Wang H J, Yuan X Z, Zhang J J, Wilkinson D P. Int J Hydrogen Energy, 2006, 31: 1838

[15] Inaba M, Kinumoto T, Kiriake M, Umebayashi R, Tasaka A, Ogumi Z. Electrochim Acta, 2006, 51: 5746

[16] Jablonski A, Lewera A. Appl Catal B, 2012, 115-116: 25

[17] Jablonski A, Kulesza P J, Lewera A. J Power Sources, 2011, 196: 4714 


\section{Graphical Abstract}

Chin. J. Catal., 2015, 36: 496-501 doi: 10.1016/S1872-2067(14)60226-6

\section{Improving the efficiency of a direct ethanol fuel cell by a periodic load change}

Andrzej Jablonski, Adam Lewera*

University of Warsaw, Poland

A very simple method of increasing direct ethanol fuel cell efficiency by over $50 \%$, and cell voltage by up to $70 \mathrm{mV}$, using periodic modulation of the load (shorting with a resistor) is presented and discussed.

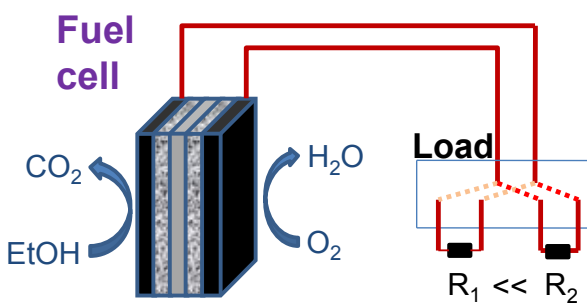

[18] Seweryn J, Lewera A. Appl Catal B, 2014, 144: 129

[19] Seweryn J, Lewera A.J Power Sources, 2012, 205: 264

[20] Vigier F, Coutanceau C, Hahn F, Belgsir E M, Lamy C. J Electroanal Chem, 2004, 563: 81

[21] Wang J T, Wasmus S, Savinell R F. J Electrochem Soc, 1995, 142: 4218

[22] Rousseau S, Coutanceau C, Lamy C, Leger J M. J Power Sources, 2006, 158: 18

[23] Jin J M, Sheng T, Lin X, Kavanagh R, Hamer P, Hu P J, Hardacre C, Martinez-Bonastre A, Sharman J, Thompsett D, Lin W F. Phys Chem Chem Phys, 2014, 16: 9432

[24] Januszewska A, Dercz G, Piwowar J, Jurczakowski R, Lewera A Chem Eur J, 2013, 19: 17159

[25] Kolary-Zurowska A, Zieleniak A, Miecznikowski K, Baranowska B, Lewera A, Fiechter S, Bogdanoff P, Dorbandt I, Marassi R, Kulesza P J. J Solid State Electrochem, 2007, 11: 915

[26] Li M, Kowal A, Sasaki K, Marinkovic N, Su D, Korach E, Liu P, Adzic R R. Electrochim Acta, 2010, 55: 4331
[27] Kowal A, Li M, Shao M, Sasaki K, Vukmirovic M B, Zhang J, Marinkovic N S, Liu P, Frenkel A I, Adzic R R. Nat Mater, 2009, 8: 325

[28] Figueiredo M C, Aran-Ais R M, Feliu J M, Kontturi K, Kallio T. J Catal, 2014, 312: 78

[29] Choban E R, Markoski L J, Wieckowski A, Kenis P J A. J Power Sources, 2004, 128: 54

[30] Jayashree R S, Gancs L, Choban E R, Primak A, Natarajan D, Markoski L J, Kenis P J A. J Am Chem Soc, 2005, 127: 16758

[31] Hitmi H, Belgsir E M, Leger J M, Lamy C, Lezna R O. Electrochim Acta, 1994, 39: 407

[32] Watanabe M, Motoo S. J Electroanal Chem Interfacial Electrochem, 1975, 60: 267

[33] Watanabe M, Motoo S. J Electroanal Chem Interfacial Electrochem, 1975, 60: 275

[34] Kutz R B, Braunschweig B, Mukherjee P, Behrens R L, Dlott D D, Wieckowski A.J Catal, 2011, 278: 181

[35] Heinen M, Jusys Z, Behm R J.J Phys Chem C, 2010, 114: 9850 